\title{
GENETIC VARIATION AMONG EGYPTIAN WHITE LUPIN (LUPINUS ALBUS L.) GENOTYPES
}

\author{
Ehab EL-HARTY ${ }^{1,2 *}$, Azzam ASHRIE ${ }^{1}$, Megahed AMMAR $^{2,3}$, Salem ALGHAMDI ${ }^{2}$ \\ ${ }^{1}$ Legume Research Section, Field Crops Research Institute, Agricultural Research Center, Giza, EGYPT. \\ ${ }^{2}$ Legume Research Unit., Plant Production Department, College of Food and Agricultural Sciences, King \\ Saud University, Riyadh, SAUDI ARABIA \\ ${ }^{3}$ Rice Research and Training Center, Field Crops Research Institute, Agricultural Research Center, \\ Sakha, EGYPT. \\ *Corresponding author:ehabelharty@gmail.com
}

Received: 05.01.2016

\begin{abstract}
Field Evaluation of eighteen lupin genotypes was carried out during 2012/13 and 2013/14 at Giza Agriculture Research Station, Egypt, to assess the genetic variation on phenological parameters. Simultaneously, molecular diversity assessment was performed using 11 SRAP primer pair combinations. High significant differences among genotypes were observed for field performance during the two seasons and their combined data. The Australian genotype $75 \mathrm{B9} .10$ and landrace Fayed1 recorded the highest seed yield/plant while the Egyptian landraces Sohag2, Fayed1 and the cultivar Giza1 were superiors in seed yield/hectare $(2.8,2.6$ and 2.6t, respectively). Only the first two principle components explained $97 \%$ of variability. Characters, number of pods, seed yield/plant and seed yield/hectare were grouped on the positive PC1 axis of the biplot with genotypes Sohag2, 75B9.10 and Fayed1. The molecular analysis revealed coherent results. The 11 SRAP primers generated 3286 amplified fragments represents 337 genetic loci across the lupin genome. The average detected loci per primer pair was 30.64 with 322 polymorphic loci across the studied genotypes $(96.05 \%)$. The polymorphism information content (PIC) values were generally high and ranged from 0.883 to 0.981 . The high PIC values highlight the power of SRAP markers in detecting the molecular diversity in lupin genotypes. The genotypes tended to cluster based on their origin and genetic background.
\end{abstract}

Key words: biplot, cluster analysis, lupin, marker, SRAP

\section{INTRODUCTION}

Lupin, an annual or perennial legume belonging to legume family, Fabaceae, is one of the oldest crops. It was a major food legume in the Roman Empire and has a long history of cultivation in the Mediterranean basin, East Africa and the Atlantic islands of the northern hemisphere (Gladstones, 1998 and Kurlovich, 2002). The earliest archaeological reports on lupines are referred to the XII dynasty of Egyptian Pharaohs (Zhukovsky, 1929), and its seeds retrieved in the tombs of $22^{\text {nd }}$ dynasty (over 2 thousand years BC). Among 300 Lupinus have been described, only five species are cultivated among which white lupin is the most important one (Hondelmann 1984). It was probably domesticated in the Aegean region (Gladstones, 1998) has increased in recently years due to its high level of protein, oil and quality dietary fiber in seed dry matter (Annicchiarico, 2008 and Bhardwaj and Hamama 2012). During 2013, around 661 thousands hectare were cultivated by lupin and the highest production areas were in Australia, Russian Federation and Ukraine (FAOSTAT, 2014).
With the purpose of producing grain and green manure, seeds and other parts that grow above the ground are used to make medicine (Jansen 2006 and Sipsas 2008). Lupin contains some secondary metabolites, including isoflavones and alkaloids such as lupines and sparteine which is removed through processing. However, there is considerable interest in white lupin also as an ingredient of functional or healthy food products, exploiting the antioxidant, anti-hypertensive, cholesterol-free, gluten-free and almost starch-free grain properties (Arnoldi 2005, Bhardwaj and Hamama 2012 and Omer et al., 2016). The key amino acids lysine, leucine and serine are in excess of about $5 \%$ of total protein with methionine greater than $1 \%$ (Wilkins and Jones 2000).

Another factor of interest is that lupines have the capacity to grow under environmental and edaphic conditions that are not tolerated by other crops (Hill 1977). It is more tolerant to salinity and heavy soils than other crops (Jansen 2006). White lupin is considered as a potential crop to be planted on abandoned mercury mines in Europe (Rocio et al., 2013). It has a relatively high 
tolerance to a number of contaminants and can act as a good phytostablizer. Also, it is being used for fishmeal (Tabrett et al., 2012).

Large genetic diversity exists in morphological and agronomic traits in L. albus (Lagunes-Espinoza 2000, Lopez-Bellido et al., 2000, Christiansen et al., 2000, Mülayim et al., 2002, Jansen 2006) as well as molecular markers level (Gilbert et al., 1999) as a result of both natural and human selection. Despite genetic variability, it has been subjected to little breeding efforts (Noffsinger $e t$ al., 2000). Therefore, farmers are still cultivating old and low yielding landraces of lupin (Christiansen et al., 2000). In Egypt, two registered cultivars were selected from landraces. Understanding crop genetics and the extent of genetic variation in seed yield components is important for future improvement of white lupin and efficient use of its genetic resources. There is a lack of genetic and molecular tools to aid the genetic breeding and improvement of this species.

SRAP is an efficient genetic marker system, it is a new marker system based on PCR reaction and more reproducible, stable and less complex compared with other molecular marker techniques. Two primers are used each of which consists of the following three elements: 1) an arbitrary filler sequence of 10 to 11 bases at 5'-end, 2) the sequence motifs CCGG and AATT in the forward and reverse primer, respectively, and 3) three selective bases at the 3'-end. The rationale behind the primer architectures is that exon sequences are known to be more GC rich than other regions of the genome. In contrast, the core sequence of the second primer (AATT) is designed to bind to AT-rich sequences, which are preferentially found in non-coding regions (Ferriol et. al., 2003, Budak et al., 2004, Esposito et al., 2007 and $\mathrm{Fu}$ et al., 2008). One advantage of SRAP marker is that it target open reading frames (ORFs) (Li and Quiros, 2001).

The objective of this study was to access genetic diversity among some local and exotic lupin genotypes at morphological and molecular levels through yield evaluation and SRAP molecular markers, respectively.

\section{MATERIALS AND METHODS}

A field experiment was carried out at Giza Agriculture Research Station, Agriculture Research Center (ARC), Egypt (30.0167 N, 31.2167 E) during 2012/13 and 2013/14 seasons to evaluate seed yield and performance among eighteen local and introduced lupin genotypes. Names, pedigree and origin of lupin genotypes are presented in Table (1).

Table 1. Names, origin and types of 18 lupin genotypes used in the study

\begin{tabular}{llc}
\hline $\begin{array}{l}\text { Genotype } \\
\text { Code }\end{array}$ & Genotype name & Origin and pedigree \\
\hline 1 & Giza 1 & Egypt, cultivar, improved from landraces \\
2 & Giza 2 & Egypt, cultivar, improved from landraces \\
3 & Line 15 & Egypt, breeding line \\
4 & Line 7 & Egypt, breeding line, mutant derived from Dijon 2 by $5 \mathrm{KR} *$ \\
5 & Line 23 & Egypt, breeding line, mutant derived from Giza 1 by $2.5 \mathrm{KR}$ \\
6 & Line 9 & Egypt, breeding line \\
7 & Line $22 / 2$ & Egypt breeding line, mutant derived from Giza 1 by $2.5 \mathrm{KR}$ \\
8 & Line 33 & Egypt breeding line, mutant derived from Giza 2 by $2.5 \mathrm{KR}$ \\
9 & Line $35 / 3$ & Egypt breeding line, mutant derived from Giza 2 by $10 \mathrm{KR}$ \\
10 & Line $37 / 3$ & Egypt breeding line, mutant derived from Giza 2 by $40 \mathrm{KR}$ \\
11 & Sohag 2 & Egypt, Sohag governorate, landraces \\
12 & Local 23 & Egypt, Giza governorate, landraces \\
13 & Ismailia 2 & Egypt, Ismailia governorate, landraces \\
14 & Fayed 1 & Egypt, Ismailia governorate, landraces \\
15 & Belbies 9 & Egypt, Al Sharqia governorate, landraces \\
16 & 75 B 15.17 & Australia, breeding line \\
17 & 75 B 9.10 & Australia, breeding line \\
18 & Dijon 2 & France, cultivar \\
\hline$*$ Kilo RAD gama-rays mutant in late generation (El-Sayad and El-Barougy 2002).
\end{tabular}

The field experiment was designed in Randomized Complete Block Design (RCBD) with three replications. Experiment plot size was $7.2 \mathrm{~m}^{2}$ (four ridges with $3 \mathrm{~m}$ long in $0.6 \mathrm{~m}$ spaced). Lupin seeds were planted on the third week of November for the two seasons in hills with $0.25 \mathrm{~m}$ apart on one side of ridge. Experimental soil was clay, $\mathrm{pH}$ 8.1 and electrical conductivity (EC) $2.8 \mathrm{dS} \mathrm{m}^{-1}$. All cultural practices were applied as recommended by ARC. At maturity, 10 plants were randomly taken from each plot to measure agro-morphological traits i.e., number of pods/plant, number of seeds/plant and seed yield/plant then number of seeds per pod and 100 seed weight were calculated by deviation of seeds yield over pods/plant and, as $(100 \mathrm{x}$ seed yield)/ number of seeds, respectively. Plants from two central lines from each plot were harvested and threshed; seed yield per plot was weighed and adjusted to ton per hectare. . Statistical analysis was performed for each season separately and after confirmation of errors compatibility for the two seasons, combined analysis was applied according to standard analysis of variance technique for RCBD design using MSTATC computer software and means were separated 
using Fisher's protected least significance difference (LSD) test at $95 \%$ level of probability (Steel and Torrie, 1980). Genotypes means of the two seasons have been planted for the principal components analysis and surveying of genetic diversity by Past software Ver. 2.17 (available

http://nhm2.uio.no/norlex/past/download.html).

For molecular characterization, lupin seeds were planted in laboratory for two-weeks. Leaves of genotypes were harvested and dropped in liquid $\mathrm{N}_{2}$. DNA isolation was carried out using a modified SDS protocol as described by Alghamdi et al., (2012). Eleven SRAP primer combinations were used to estimate genetic diversity among lupin genotypes. The SRAP primer combinations used are shown in Table 2. SRAP-PCR reactions were performed in $20 \mu \mathrm{l}$ volume containing $1 \mathrm{X}$ GoTaq Green Master Mix (Cat. No. M7123, Promega Corporation, Madison, USA), $0.25 \mu \mathrm{M}$ from each forward and reverse primers, $50 \mathrm{ng}$ template DNA and nucleasefree water up to $20 \mu \mathrm{l}$. The forward primers were 5'end labelled with FAM dye. PCR amplification was carried out on a TC-5000 thermal cycler (Bibby Scientific - UK) as follows: initial denaturation at $94^{\circ} \mathrm{C}$ for $5 \mathrm{~min}$ followed by five cycles of denaturing at $94^{\circ} \mathrm{C}$ for $1 \mathrm{~min}$, annealing at $35^{\circ} \mathrm{C}$ for $1 \mathrm{~min}$ and elongation at $72^{\circ} \mathrm{C}$ for $1 \mathrm{~min}$. In the remaining 30 cycles, the annealing temperature was increased to $50^{\circ} \mathrm{C}$ for $1 \mathrm{~min}$ with a final extension step at $72^{\circ} \mathrm{C}$ for $7 \mathrm{~min}$. One microliter of amplified PCR product was mixed with $0.5 \mu \mathrm{l}$ of the GeneScan 500 LIZ size standard (Applied Biosystems $\mathrm{P} / \mathrm{N}$ 4322682) and $9 \mu \mathrm{l}$ of Hi-Di Formamide (Applied Biosystems P/N 4311320). The mixture was denatured for 3 minutes at $95^{\circ} \mathrm{C}$ and loaded on the 36-cm 16-capillary system of the Applied Biosystems 3130xl Genetic Analyzer. Fragment analysis for SRAP was performed with GeneMapper Analysis Software v3.7 (ABI) and data were assembled in binary format (allele presence (1) or (0) for Absence). The threshold for allele calling was set at 200 relative florescence units (rfu), so that any peaks at 200 or higher were assigned a 1 and those that were lower were assigned a 0 . Fragment analysis was carried out for allele sizes in the range of $100-500 \mathrm{bp}$. Markers showed single allele across genotypes were eliminated from the analysis. Data generating from SRAP analysis were analyzed using Jaccard similarity coefficient (Jaccard, 1908). Dendrogram was constructed unweighted pair group method with arithmetic average (UPGMA) employing the SAHN (sequential, agglomerative, hierarchical, and nested clustering) from the NTSYSpc (ver.2.10) program (Rohlf, 2005).

Table 2. List SRAP primer combinations used to access molecular diversity in lupin

\begin{tabular}{cll}
\hline No. & \multicolumn{1}{c}{ Forward 5'-3' } & \multicolumn{1}{c}{ Reverse 5'-3' } \\
\hline 1 & SRAP13. 5-GAC TGC GTA CGA ATT CAA-3 & SRAP6. 5-GACTGCGTACGAATTAAT-3 \\
2 & SRAP13. 5-GAC TGC GTA CGA ATT CAA-3 & SRAP7. 5-GACTGCGTACGAATTTGC-3 \\
3 & SRAP13. 5-GAC TGC GTA CGA ATT CAA-3 & SRAP9. 5-GACTGCGTACGAATTTGA-3 \\
4 & SRAP13. 5-GAC TGC GTA CGA ATT CAA-3 & SRAP11. 5-GACTGCGTACGAATTGCA-3 \\
5 & SRAP15. 5-CGT AGC GCG TCA ATT ATG-3 & SRAP4. 5-TGAGTCCAAACCGGACC-3 \\
6 & SRAP15. 5-CGT AGC GCG TCA ATT ATG-3 & SRAP5. 5-TGAGTCCAAACCGGAAG-3 \\
7 & SRAP15. 5-CGT AGC GCG TCA ATT ATG-3 & SRAP6. 5-GACTGCGTACGAATTAAT-3 \\
8 & SRAP15. 5-CGT AGC GCG TCA ATT ATG-3 & SRAP9. 5-GACTGCGTACGAATTTGA-3 \\
9 & SRAP16. 5-GGA ACC AAA CAC ATG AAG A-3 & SRAP3. 5-TGAGTCCAAACCGGAAT-3 \\
10 & SRAP16. 5-GGA ACC AAA CAC ATG AAG A-3 & SRAP6. 5-GACTGCGTACGAATTAAT-3 \\
11 & SRAP16. 5-GGA ACC AAA CAC ATG AAG A-3 & SRAP9. 5-GACTGCGTACGAATTTGA-3 \\
\hline
\end{tabular}

\section{RESULTS AND DISCUSSION}

\section{Field performance}

Results showed highly significant differences among studied white lupin genotypes that demonstrated the extended of genetic diversity in genetic materials used for this study. Genotype $\mathrm{x}$ season interactions were significant for all studied traits except number of seeds $\operatorname{pod}^{-1}$ but the genotypic variances were higher than genotype $\mathrm{x}$ season interactions variances for all studied traits indicating a relatively constant ranking of genotypes across the two seasons. Furthermore, seasonal differences were significant only for number of seeds $\operatorname{pod}^{-1}$ and 100 seed weight. These findings closely match previous evaluation results of Christiansen et. al., (2000), Annicchiarico et al., (2010), Mut et al., (2012). Raza and Jornsgard (2005) reported significant differences between the Egyptian landraces in yield components in different environments but seasonal variance was insignificant for plant height, number of branches, pods plant ${ }^{-1}$ and seeds pod ${ }^{-1}$.

Mean of seed yield and its components for the studied genotypes are presented in Tables $3 \& 4$. Number of pods/pant had overall average of 22.8 and ranged from 15.2 pods for Belibies9 to 30.5 for the genotype $75 \mathrm{~B}$ 15.17. Concerning number of seeds/plant, genotypes $75 \mathrm{~B}$ 9.10, Local23 and Giza2 had the more number of seeds/plant (105.2, 103.3 and 98.7), while Belibies9 had the lowest value of 47.2. Significant differences among genotypes were detected for number of seeds $\operatorname{pod}^{-1}$ and the highest number found in genotypes Ismailia2 and Line23 where they had 4.4 and 4.3 seeds/pod, respectively (Table 3).

Results showed that heavier lupin seeds were recorded in Ismailia2, with 100 seed weight of $43.7 \mathrm{~g}$ which exceeded genotypes overall average (35.4 g) by $23 \%$ 
(Table 4). The best seed yield per plant was produced by the Australian genotype 75B9.10 (38.3g) closely followed by the landrace Fayed 1 (38.2g) (Table 4). These two genotypes exceeded old local cultivars by $42 \%$. However, seed yield plant ${ }^{-1}$, was not linear with plot yield converted to $\mathrm{th}^{-1}$. The promising performers in seed yield as tons ha $^{-1}$ were Sohag2, Fayed1 and Giza1, with 2.8, 2.6 and 2.6 $\mathrm{t} \mathrm{ha}^{-1}$, respectively. The Australian genotype 75B9.10 ranked fourth with little significant differences and mean value of $2.3 \mathrm{t}$. However, the super landraces (Sohag2 and
Fayed1) ranked second in most studied traits. Genotypes that were superior in one of yield components can be involve in breeding program such as line 15 for pods plant ${ }^{-}$ ${ }^{1}$, Local23 for seeds plant ${ }^{-1}$ and Dijon2, Ismailia2, Line23 and Giza1 for seeds $\operatorname{pod}^{-1}$ and Ismailia2 for 100 seed weight. These results showed the importance of landraces in breeding program and this was in agreement with the results of Christiansen et al., (2000), Raza and Jornsgard (2005), Gonzalez-Andres et al.,(2007),Annicchiarico et al., (2010), Faligowska and Szukała (2015).

Table 3. Number of pods and seeds per plant and per pod of the eighteen lupin genotypes during two seasons and their combined.

\begin{tabular}{|c|c|c|c|c|c|c|c|c|c|}
\hline \multirow{2}{*}{ Genotype } & \multicolumn{3}{|c|}{ No. of pods plant ${ }^{-1}$} & \multicolumn{3}{|c|}{ No. of seeds plant ${ }^{-1}$} & \multicolumn{3}{|c|}{ No. of seeds pod ${ }^{-1}$} \\
\hline & $1^{\text {st }}$ season & $2^{\text {nd }}$ season & Combined & $\mathbf{1}^{\text {st }}$ season & $2^{\text {nd }}$ season & Combined & $\mathbf{1}^{\text {st }}$ season & $2^{\text {nd }}$ season & Combined \\
\hline Giza 1 & 17.7 C-F & $22.3 \mathrm{~B}-\mathrm{F}$ & $20.0 \mathrm{~b}-\mathrm{f}$ & $75.7 \mathrm{~B}-\mathrm{G}$ & $88.7 \mathrm{~A}-\mathrm{F}$ & 82.2 bcd & 4.3 & 4.0 & $4.2 \mathrm{a}$ \\
\hline Giza2 & $25.3 \mathrm{~A}-\mathrm{E}$ & 26.0 A-D & $25.6 \mathrm{abc}$ & $96.0 \mathrm{~A}-\mathrm{D}$ & $101.3 \mathrm{ABC}$ & $98.7 \mathrm{ab}$ & 3.9 & 3.9 & $3.9 \mathrm{ab}$ \\
\hline Line 15 & $29.3 \mathrm{ABC}$ & $31.3 \mathrm{AB}$ & $30.3 \mathrm{a}$ & $84.0 \mathrm{~B}-\mathrm{G}$ & 79.7 B-G & $81.8 \mathrm{bcd}$ & 3.0 & 2.6 & $2.8 \mathrm{~b}$ \\
\hline Line 7 & $18.7 \mathrm{C}-\mathrm{F}$ & $21.3 \mathrm{~B}-\mathrm{F}$ & $20.0 \mathrm{~b}-\mathrm{f}$ & $76.3 \mathrm{~B}-\mathrm{G}$ & $84.3 \mathrm{~B}-\mathrm{G}$ & $80.3 \mathrm{bcd}$ & 4.1 & 4.0 & $4.0 \mathrm{ab}$ \\
\hline Line 23 & $21.3 \mathrm{~B}-\mathrm{F}$ & $24.0 \mathrm{~A}-\mathrm{E}$ & $22.7 b-f$ & $93.0 \mathrm{~A}-\mathrm{E}$ & $98.3 \mathrm{ABC}$ & $95.7 \mathrm{abc}$ & 4.5 & 4.1 & $4.3 \mathrm{a}$ \\
\hline Line 9 & $24.0 \mathrm{~A}-\mathrm{E}$ & 23.3 B-E & $23.7 \mathrm{a}-\mathrm{e}$ & 81.7 B-G & $92.0 \mathrm{~A}-\mathrm{E}$ & 86.8 a-d & 3.5 & 3.9 & $3.7 \mathrm{ab}$ \\
\hline Line 22/2 & $17.7 \mathrm{C}-\mathrm{F}$ & $23.0 \mathrm{~B}-\mathrm{E}$ & $20.3 b-f$ & 61.3 FGH & 79.7 B-G & $70.5 \mathrm{de}$ & 3.6 & 3.5 & $3.5 \mathrm{ab}$ \\
\hline Line 33 & $14.0 \mathrm{EF}$ & 19.0 C-F & 16.5 ef & $56.3 \mathrm{GH}$ & $65.0 \mathrm{E}-\mathrm{H}$ & 60.7 ef & 4.1 & 3.4 & $3.8 \mathrm{ab}$ \\
\hline Line 35/3 & 22.7 B-F & 26.0 A-D & $24.3 \mathrm{a}-\mathrm{d}$ & $93.7 \mathrm{~A}-\mathrm{E}$ & 92.7 A-E & $93.2 \mathrm{abc}$ & 4.2 & 3.6 & $3.9 \mathrm{ab}$ \\
\hline Line 37/3 & 19.7 B-F & $25.0 \mathrm{~A}-\mathrm{E}$ & $22.3 \mathrm{~b}-\mathrm{f}$ & $83.0 \mathrm{~B}-\mathrm{G}$ & 79.7 B-G & $81.3 \mathrm{bcd}$ & 4.3 & 3.2 & $3.7 \mathrm{ab}$ \\
\hline Sohag 2 & $25.3 \mathrm{~A}-\mathrm{E}$ & $25.0 \mathrm{~A}-\mathrm{E}$ & $25.2 \mathrm{abc}$ & 96.7 A-D & $90.0 \mathrm{~A}-\mathrm{F}$ & $93.3 \mathrm{abc}$ & 4.0 & 3.6 & $3.8 \mathrm{ab}$ \\
\hline Local 23 & $24.0 \mathrm{~A}-\mathrm{E}$ & $27.7 \mathrm{ABC}$ & $25.8 \mathrm{abc}$ & $101.3 \mathrm{ABC}$ & $105.3 \mathrm{AB}$ & $103.3 \mathrm{a}$ & 4.3 & 3.9 & $4.1 \mathrm{ab}$ \\
\hline Ismailia 2 & 15.0 DEF & $19.3 \mathrm{C}-\mathrm{F}$ & $17.2 \mathrm{def}$ & $68.3 \mathrm{D}-\mathrm{G}$ & 74.7 C-G & $71.5 \mathrm{de}$ & 4.9 & 3.9 & $4.4 \mathrm{a}$ \\
\hline Fayed 1 & $28.0 \mathrm{ABC}$ & 26.0 A-D & $27.0 \mathrm{ab}$ & $93.3 \mathrm{~A}-\mathrm{E}$ & $100.3 \mathrm{ABC}$ & $96.8 \mathrm{abc}$ & 3.3 & 3.9 & $3.6 \mathrm{ab}$ \\
\hline Belibies 9 & $11.0 \mathrm{~F}$ & 19.3 C-F & $15.2 \mathrm{f}$ & $37.7 \mathrm{H}$ & $56.7 \mathrm{GH}$ & $47.2 \mathrm{f}$ & 3.4 & 2.9 & $3.2 \mathrm{ab}$ \\
\hline 75 B 15.17 & $25.5 \mathrm{~A}-\mathrm{E}$ & $21.7 \mathrm{~B}-\mathrm{F}$ & 23.6 a-e & $102.5 \mathrm{ABC}$ & $85.0 \mathrm{~B}-\mathrm{G}$ & $93.8 \mathrm{abc}$ & 4.1 & 3.9 & $4.0 \mathrm{ab}$ \\
\hline 75 B 9.10 & $35.7 \mathrm{~A}$ & $25.3 \mathrm{~A}-\mathrm{E}$ & $30.5 \mathrm{a}$ & $115.7 \mathrm{~A}$ & $94.7 \mathrm{~A}-\mathrm{E}$ & $105.2 \mathrm{a}$ & 3.2 & 3.8 & $3.5 \mathrm{ab}$ \\
\hline Dijon 2 & 15.7 DEF & 22.7 B-F & $19.7 \mathrm{c}-\mathrm{f}$ & 73.0 C-G & $85.0 \mathrm{~B}-\mathrm{G}$ & 79.0 cde & 4.8 & 3.9 & $4.4 \mathrm{a}$ \\
\hline Mean & 21.7 & 23.8 & 22.8 & 82.8 & 86.3 & 84.5 & 4.0 & 3.7 & 3.8 \\
\hline
\end{tabular}

Interaction and mean of the two seasons haring the same case letter, for a parameter, do not differ significantly at P 0.05 .

Table 4. 100seed weight, seed yield per plant $(\mathrm{g})$ and as ton per hectare of the eighteen lupin genotypes during two seasons and their combined.

\begin{tabular}{|c|c|c|c|c|c|c|c|c|c|}
\hline \multirow{2}{*}{ Genotype } & \multicolumn{3}{|c|}{100 seed weight $(\mathrm{g})$} & \multicolumn{3}{|c|}{ Seed yield plant ${ }^{-1}(\mathrm{~g})$} & \multicolumn{3}{|c|}{ Seed yield $\left(\mathrm{t} \mathrm{ha}^{-1}\right)$} \\
\hline & $1^{\text {st }}$ season & $2^{\text {nd }}$ season & Combined & $1^{\text {st }}$ season & $2^{\text {nd }}$ season & Combined & $1^{\text {st }}$ season & $2^{\text {nd }}$ season & Combined \\
\hline Giza 1 & $30.9 \mathrm{ABC}$ & $30.6 \mathrm{ABC}$ & $30.8 \mathrm{~b}$ & 23.3 E-I & 27.0 C-I & $25.2 \mathrm{~cd}$ & $2.4 \mathrm{~A}-\mathrm{E}$ & $2.7 \mathrm{ABC}$ & $2.6 \mathrm{ab}$ \\
\hline Giza2 & $26.20 \mathrm{C}$ & $35.6 \mathrm{ABC}$ & $30.9 \mathrm{~b}$ & 25.3 C-I & $32.0 \mathrm{~A}-\mathrm{F}$ & $28.7 \mathrm{c}$ & $1.8 \mathrm{CDE}$ & $2.7 \mathrm{ABC}$ & $2.2 \mathrm{a}-\mathrm{e}$ \\
\hline Line 15 & $37.1 \mathrm{ABC}$ & $33.6 \mathrm{ABC}$ & $35.4 \mathrm{ab}$ & $31.0 \mathrm{~A}-\mathrm{F}$ & 26.6 C-I & $28.8 \mathrm{c}$ & $2.3 \mathrm{~A}-\mathrm{E}$ & $1.6 \mathrm{E}$ & $1.9 \mathrm{cde}$ \\
\hline Line 7 & $31.7 \mathrm{ABC}$ & $37.5 \mathrm{ABC}$ & $34.6 \mathrm{ab}$ & 24.0 D-I & $31.7 \mathrm{~A}-\mathrm{F}$ & $27.8 \mathrm{c}$ & $2.3 \mathrm{~A}-\mathrm{E}$ & $2.3 \mathrm{~A}-\mathrm{E}$ & $2.3 \mathrm{abc}$ \\
\hline Line 23 & $31.8 \mathrm{ABC}$ & $34.6 \mathrm{ABC}$ & $33.2 \mathrm{~b}$ & $29.3 \mathrm{~A}-\mathrm{G}$ & $34.0 \mathrm{~A}-\mathrm{E}$ & $31.7 \mathrm{abc}$ & $1.7 \mathrm{DE}$ & $1.8 \mathrm{DE}$ & $1.7 \mathrm{de}$ \\
\hline Line 9 & $36.6 \mathrm{ABC}$ & $32.6 \mathrm{ABC}$ & $34.6 \mathrm{ab}$ & $30.0 \mathrm{~A}-\mathrm{F}$ & $30.0 \mathrm{~A}-\mathrm{F}$ & $30.0 \mathrm{bc}$ & $2.6 \mathrm{~A}-\mathrm{D}$ & $2.1 \mathrm{~B}-\mathrm{E}$ & $2.3 \mathrm{abc}$ \\
\hline Line $22 / 2$ & $42.2 \mathrm{AB}$ & $33.1 \mathrm{ABC}$ & $37.6 \mathrm{ab}$ & 25.3 C-I & $26.3 \mathrm{C}-\mathrm{I}$ & $25.8 \mathrm{~cd}$ & $2.3 \mathrm{~A}-\mathrm{E}$ & $2.3 \mathrm{~A}-\mathrm{E}$ & $2.3 \mathrm{a}-\mathrm{d}$ \\
\hline Line 33 & $31.8 \mathrm{ABC}$ & $33.3 \mathrm{ABC}$ & $32.6 \mathrm{~b}$ & $18.0 \mathrm{GHI}$ & 21.7 F-I & $19.8 \mathrm{de}$ & $1.8 \mathrm{CDE}$ & $2.2 \mathrm{~A}-\mathrm{E}$ & $2.0 \mathrm{~b}-\mathrm{e}$ \\
\hline Line 35/3 & $30.5 \mathrm{ABC}$ & $35.7 \mathrm{ABC}$ & $33.1 \mathrm{~b}$ & $28.7 \mathrm{~B}-\mathrm{G}$ & $33.0 \mathrm{~A}-\mathrm{F}$ & $30.8 \mathrm{abc}$ & $1.8 \mathrm{DE}$ & $1.8 \mathrm{CDE}$ & $1.8 \mathrm{cde}$ \\
\hline Line 37/3 & $38.1 \mathrm{ABC}$ & $38.5 \mathrm{ABC}$ & $38.3 \mathrm{ab}$ & $31.7 \mathrm{~A}-\mathrm{F}$ & $30.7 \mathrm{~A}-\mathrm{F}$ & $31.2 \mathrm{abc}$ & $1.7 \mathrm{DE}$ & $2.2 \mathrm{~A}-\mathrm{E}$ & $2.0 \mathrm{cde}$ \\
\hline Sohag 2 & $37.9 \mathrm{ABC}$ & $36.2 \mathrm{ABC}$ & $37.0 \mathrm{ab}$ & $36.3 \mathrm{ABC}$ & $36.7 \mathrm{ABC}$ & $36.5 \mathrm{ab}$ & $2.5 \mathrm{~A}-\mathrm{D}$ & $3.0 \mathrm{~A}$ & $2.8 \mathrm{a}$ \\
\hline Local 23 & $30.2 \mathrm{ABC}$ & $31.4 \mathrm{ABC}$ & $30.8 \mathrm{~b}$ & $30.3 \mathrm{~A}-\mathrm{F}$ & $33.3 \mathrm{~A}-\mathrm{F}$ & $31.8 \mathrm{abc}$ & $1.7 \mathrm{DE}$ & $1.7 \mathrm{DE}$ & $1.7 \mathrm{e}$ \\
\hline Ismailia 2 & $42.7 \mathrm{AB}$ & $44.6 \mathrm{~A}$ & $43.7 \mathrm{a}$ & $29.0 \mathrm{~B}-\mathrm{G}$ & $33.7 \mathrm{~A}-\mathrm{E}$ & $31.3 \mathrm{abc}$ & $1.7 \mathrm{DE}$ & $1.9 \mathrm{CDE}$ & $1.8 \mathrm{cde}$ \\
\hline Fayed 1 & $42.4 \mathrm{AB}$ & $37.2 \mathrm{ABC}$ & $39.8 \mathrm{ab}$ & $39.3 \mathrm{AB}$ & $37.0 \mathrm{ABC}$ & $38.2 \mathrm{a}$ & $2.9 \mathrm{AB}$ & $2.4 \mathrm{~A}-\mathrm{E}$ & $2.6 \mathrm{ab}$ \\
\hline Belibies 9 & $40.8 \mathrm{ABC}$ & $29.3 \mathrm{BC}$ & $35.1 \mathrm{ab}$ & $15.3 \mathrm{I}$ & $16.3 \mathrm{HI}$ & $15.8 \mathrm{e}$ & $1.9 \mathrm{CDE}$ & $1.8 \mathrm{DE}$ & $1.9 \mathrm{cde}$ \\
\hline 75 B 15.17 & $32.7 \mathrm{ABC}$ & $32.2 \mathrm{ABC}$ & $32.4 \mathrm{~b}$ & $33.5 \mathrm{~A}-\mathrm{F}$ & $27.3 \mathrm{C}-\mathrm{H}$ & $30.4 \mathrm{bc}$ & $1.8 \mathrm{DE}$ & $1.9 \mathrm{CDE}$ & $1.8 \mathrm{cde}$ \\
\hline 75 B 9.10 & $36.1 \mathrm{ABC}$ & $37.6 \mathrm{ABC}$ & $36.9 \mathrm{ab}$ & $41.0 \mathrm{~A}$ & 35.7 A-D & $38.3 \mathrm{a}$ & $2.4 \mathrm{~A}-\mathrm{E}$ & $2.1 \mathrm{~A}-\mathrm{E}$ & $2.3 \mathrm{a}-\mathrm{e}$ \\
\hline Dijon 2 & $39.7 \mathrm{ABC}$ & $40.2 \mathrm{ABC}$ & $39.9 \mathrm{ab}$ & $28.7 \mathrm{~B}-\mathrm{G}$ & $33.7 \mathrm{~A}-\mathrm{E}$ & $31.2 \mathrm{abc}$ & $2.2 \mathrm{~A}-\mathrm{E}$ & $1.8 \mathrm{CDE}$ & $2.0 \mathrm{~b}-\mathrm{e}$ \\
\hline Mean & 35.5 & 35.2 & 35.4 & 28.9 & 30.4 & 29.6 & 2.1 & 2.1 & 2.1 \\
\hline
\end{tabular}

Interaction and mean of the two seasons haring the same case letter, for a parameter, do not differ significantly at P 0.05 .

Through principal components analysis, genotypes are grouped on the basis of first two components. PC clarifies genotypes on the basis of trait's weight in every component to get special position in correlation with agronomic traits. Genotypes are scattered according to the correlation of considered traits with components and according to the quantity of under study traits. This kind of genotype scattering in provided vectors can provide at least the possibility of fast omission or selection of main parts of genotypes and this can be useful in preliminary 
evaluations. The principal component analysis (PCA) was performed to access relationships of genotypes and studied traits (Figure 1) which revealed the two most informative principal components with eigenvalues of 269.4 and 20.4 which together explained $97 \%$ of the total variance. Thus, according to the first two PC, characters number of pods, seed yield plant ${ }^{-1}$ and seed yield hectare ${ }^{-1}$ were grouped on the positive PC1 axis of the biplot, suggesting strong relationships among these characters and genotypes Sohag2, 75B9.10 and Fayed1. On the other side, number of seeds plant ${ }^{-1}$ and seeds pod $^{-1}$ grouped with the Giza2, Local23, 75B15.17, Line9, Line35/3, Line23. Identify genotypes with characteristics different from those of old cultivars (Giza1 and Giza2) are the first step in breeding program. These findings closely correspond to previous finds of Rubio et al. (2004), Gonzalez-Andres et al., (2007), Hefany (2013) and Sabaghnia (2015).

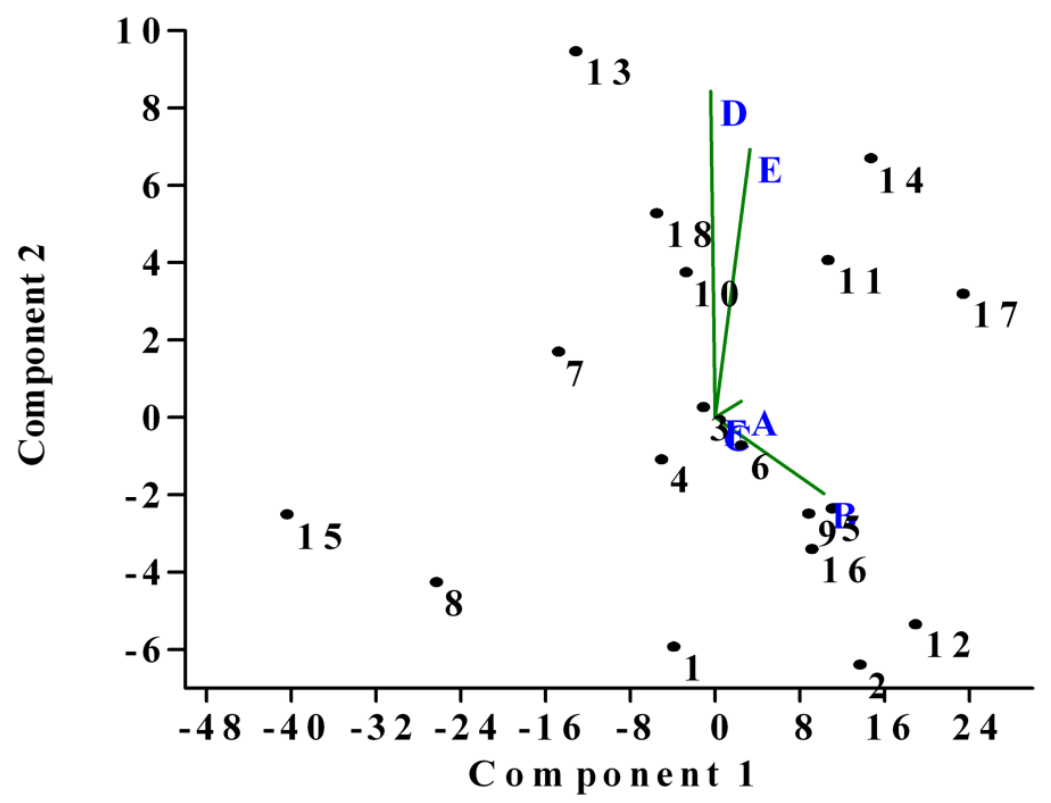

Figure 1. Biplot analysis for A, pods; B, seeds; C, seeds $\operatorname{pod}^{-1} ; \mathrm{D}, 100$ seed weight; E, seed yield plant ${ }^{-1}$ and F, seed yield hectare ${ }^{-1}$ and code of genotypes.

\section{Molecular analysis}

Innovations in molecular marker systems are employed by many branches of the plant sciences to elucidate and access genetic diversity at molecular levels (Robarts and Wolfe 2014). Over the past decade, application of SRAP markers has gained momentum, especially in the applied plant sciences (Aneja et al. 2012). SRAP marker system is considered suitable for diversity assessment in plants (Wang 2012). The results obtained here revealed the power of SRAP markers in detecting molecular diversity. Eleven SRAP primer combinations gave reproducible results out of 24 combinations initially tested. The summaries of obtained results are presented in Table 5. A total of 3268 amplicons were generated with average of 298.73 amplified fragments per primer pair across the eighteen studied lupin genotypes. The total number of genetic loci amplified was 337 with average of 30.65 loci primer ${ }^{-1}$. The polymorphism percentage for the studied primer pairs ranged from $83.9 \%$ in the primer ME13 x EM6 to $100 \%$ in eight studied primers. The PIC values ranged from 0.883 in ME15 x EM6 primer combination to 0.981in the primer ME13 x EM6. The studied genotypes showed significant diversity as the closest genotypes were Giza1 and Ismailia2, as well as Line37/3 and Line22/2, with similarity percentage of $65 \%$ each. On the other hand, the genotype pair Sohag2 and 75B15-17 showed only 39\% similarity. Based on the SRAP scored patterns, UPGMAbased clustering analysis was performed. The dendrogram explaining the genetic relationship among the lupin studied genotypes is presented in Fig. 2. The coefficient of similarity ranged from 0.40 to 0.69 . The studied genotypes were clustered initially into two main groups at $40 \%$ similarity, with a main group including all genotypes and ungrouped 75B15-17 genotype as the most diverse genotype across all studied genotypes. The number of sub clusters formed in the main group suggests the existence of considerable amounts of genetic variations among tested genotypes. At 0.69 similarity coefficient, all genotypes were distinguished and separated from each other (Fig. 2). Similar results have been reported by many researchers on other plant species (Alghamdi et al. 2012 and Liu et al. 2015). Yet, diversity assessments using other marker systems were employed to lupin genotypes. Yorgancilar et al. (2009) used RAPD and ISSR markers to determine the genetic relationships among 20 old world lupin genotypes and noticed that there are relationship 
between Egyptian and some USA genotypes and be distinct from European landraces. EL-Sherif et al. speculated that USA-6313 genotype was selected from (2014) estimated genetic relationships among eighteen Egyptian origin materials. In study of Raman et al. (2008) white lupin (Lupinus albus L.) genotypes, using ISSR and using Intron-Targeted Amplified Polymorphisms (ITAPs), AFLP markers. They found that some genotypes represent SSR motifs, and DArT markers reported that Australian a relation to their distribution position also Giza2 cultivar cultivars and breeding lines were clustered and tended to and landrace from Sohag are clustered together.

Table 5. Summary of SRAP primer combinations data on the 18 tested lupin genotypes

Primer combination Total \# of fragments Total \# of loci Polymorphic loci \% Polymorphism PIC value

\begin{tabular}{lccccc}
\hline ME13 x EM6 & 697 & 62 & 52 & 83.9 & 0.981 \\
ME13 x EM7 & 574 & 48 & 52 & 100 & 0.977 \\
ME13 x EM9 & 419 & 35 & 28 & 80 & 0.966 \\
ME13 x EM11 & 295 & 27 & 27 & 100 & 0.959 \\
ME15 x EM4 & 115 & 13 & 13 & 100 & 0.915 \\
ME15 x EM5 & 90 & 17 & 17 & 100 & 0.934 \\
ME15 x EM6 & 47 & 8 & 8 & 100 & 0.883 \\
ME15 x EM9 & 272 & 27 & 25 & 92.6 & 0.954 \\
ME16 x EM3 & 227 & 30 & 30 & 100 & 0.953 \\
ME16 x EM6 & 240 & 37 & 37 & 100 & 0.956 \\
ME16 x EM9 & 310 & 33 & 33 & 100 & 0.963 \\
\hline Total & 3286 & 337 & 322 & & \\
\hline Average & 298.73 & 30.64 & 29.27 & 96.05 & 0.949 \\
\hline
\end{tabular}

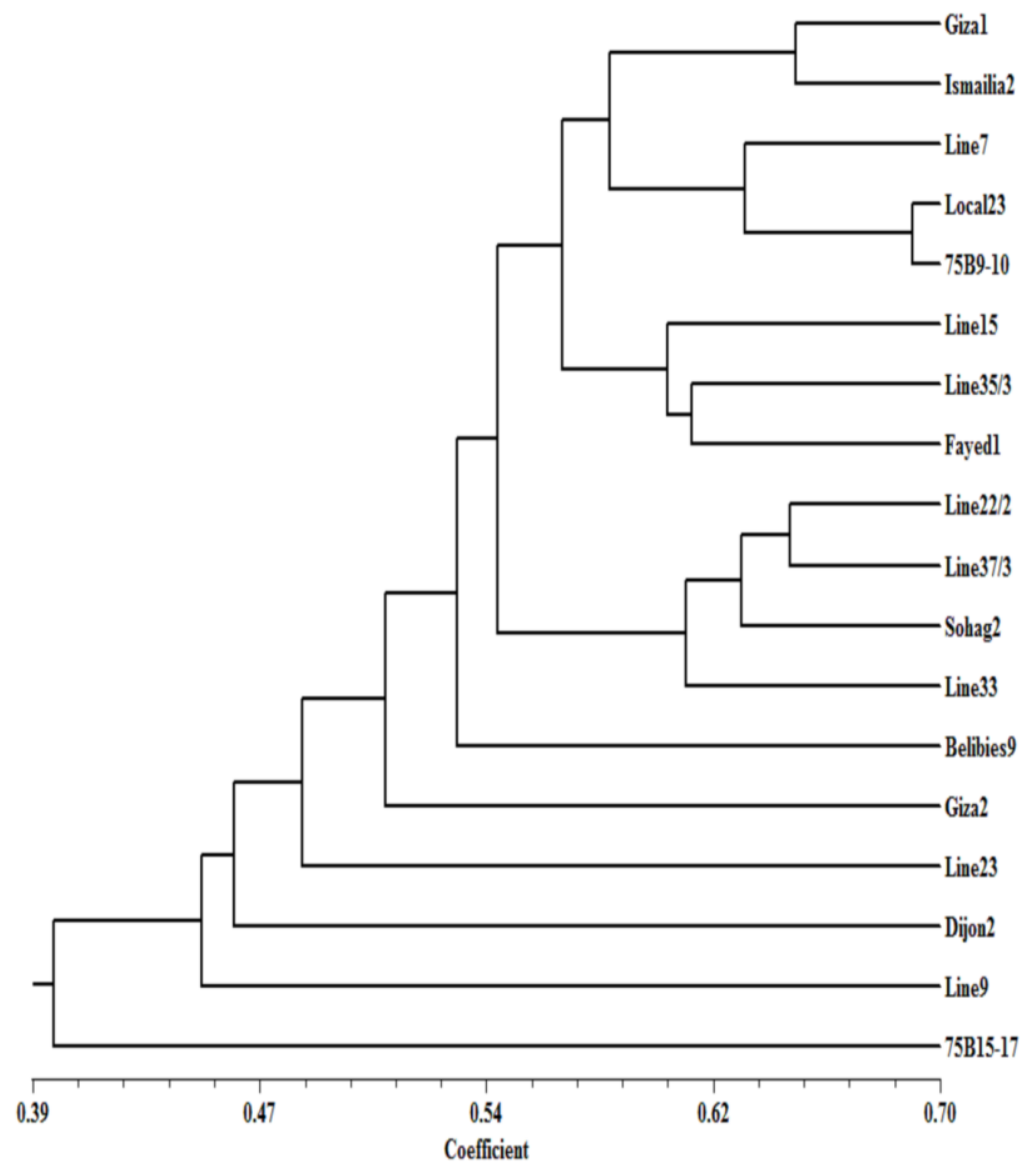

Figure 2. Dendrogram explaining the genetic releationship among studied genotypes as revealed by SRAP data. 
The use of SRAP marker system could be helpful in varietal identification, fingerprinting, diversity assessment, mapping and tagging economically important traits in lupin. This could help to development of genetic tools for lupin improvement.

\section{ACKNOWLEDGEMENT}

The authors would like to extend their sincere appreciation to the Deanship of the Scientific Research at King Saud University/Agricultural Research Center for their financial support

\section{LITERATURE CITED}

Alghamdi, S., S. Al-Faifi, H. Migdadi, M. Khan, E. EL-Harty and M. Ammar 2012. Molecular diversity assessment using sequence related amplified polymorphism (SRAP) markers in Vicia faba L. Int. J. Mol. Sci. $13: 16457-16471$.

Aneja, B., N.R. Yadav, V. Chawla and R.C. Yadav 2012. Sequence-related amplified polymorphism (SRAP) molecular marker system and its applications in crop improvement. Molecular Breeding 30 :1635-1648.

Annicchiarico, P. 2008. Adaptation of cool-season grain legume species across climatically-contrasting environments of southern Europe. Agron. J. 100 :1647-1654.

Annicchiarico, P., N. Harzic and A.M. Carroni 2010 Adaptation,diversity, and exploitation of global white lupin (Lupinus albus L.) landrace genetic resources. Field Crops Research, $119: 114-124$.

Arnoldi, A. 2005. The Healthy-Profood Project: optimized process for preparing healthy and added value food ingredients from lupin kernels, the European protein-rich legume. In: Final Conference of Healthy-Profood :1-8 Milan 9-18 November.

Bhardwaj, H. L. and A.A. Hamama 2012. Yield and Nutritional Quality Traits of White Lupin Sprouts. Journal of Agricultural Science $4: 58-61$.

Budak, H., R.C. Shearman and D. Parmaksiz 2004. Comparative analysis of seeded and vegetative biotype buffalo grasses based o phylogenetic relationship using ISSRs, SSRs, RAPDs, and SRAPs. Theor. Appl. Genet. 109 :280-288.

Christiansen, J.L., S. Raza, B. Jornsgard, S.A. Mahmoud and R. Ortiz 2000. Potential of landrace germplasm for genetic enhancement of white lupin in Egypt. Genetic Resources and Crop Evolution 47 :425-430.

El-Sayad, Z. S. and E. El-Barougy 2002. Development of some white lupin mutant lines high yielding, early maturing and resistant to Fusarium wilt. Annals Agric. Sci. 47 : 641- 657.

EL-Sherif, N.A., A.A. Mohamed, M.E. Saad, H. Barakat and S. Aly 2014. Genetic variation in Egyptian white lupin (Lupinus albus L.) genotypes based on combined data of ISSR and fluorescence-based AFLP markers. Egypt. J. Genet. Cytol. $43: 1-23$.

Esposito, M.A., E.A. Martin, V.P. Cravero and E. Cointry 2007. Characterization of pea accessions by SRAP's markers. Sci. Hortic. 113 :329-335.

FAOSTAT, 2014. http://faostat3.fao.org/home/E

Faligowska, A. and J. Szukała 2015. The effect of various longterm tillage systems on yield and yield component of yellow and narrow-leaved lupin. Turk J Field Crops 20 (2) :188 193.

Ferrio, M., B. Pico and F. Nuez 2003. Genetic diversity of a germplasm collection of Cucurbita pepo using SRAP and AFLP markers. Theor. Appl. Genet. 107 :271-282.

Fu, X., G. Ning, L. Gao and M. Bao 2008. Genetic diversity of Dianthus accessions as assessed using two molecular marker systems (SRAPs and ISSRs) and morphological traits. Sci. Hortic. $117: 263-270$.

Gilbert, G.A., J.D. Knight, C.P. Vance and D.L. Allan 1999. Acid phosphatase activity in phosphorus -deficient white lupin roots. Plant Cell and Environment 22 :801-810.

Gladstones, J.S. 1998. Distribution, Origin, Taxonomy, History and Importance. In: Lupin as Crop Plants. eds. J.S. Gladstones, C.A. Atkins and J. Hamblin et al. :1-39. Biology, Production and Utilization. CAB International, Oxon, UK

Gonzalez-Andres, F., P. A. Casquero, C. San-Pedro and E. Hernandez-Sanchez 2007. Diversity in white lupin (Lupinus albus L.) landraces from northwest Iberian plateau. Genetic Resources and Crop Evolution 54 :27-44.

Hefany, M. M. 2013. Use of genetic variability estimates and interrelationships of agronomic and biochemical characters for selection of lupin genotypes under different irrigation regimes. African Crop Science Journal $21: 97-108$.

Hill, G. D. 1977. The composition and nutritive value of lupin seed. Live-stock feeds \& feeding 47: 511-529.

Hondelmann, W. 1984. The lupin: Ancient and modern crop plant. Theor. Appl. Genet., $68: 1-9$.

Jaccard, P. 1908. Nouvelles recherches sur la distribution florale. Bull. Soc. Vaudoise Sci. Nat. 44 :223-270.

Jansen, P. C. M. 2006. Lupinus albus (L.) Record from Protabase. In: PROTA (Plant Resources of Tropical Africa. eds. Brink, M. and G. Belay, Wageningen, Netherlands.

Kurlovich, B.S. 2002. Lupins: Geography, Classification, Genetic Resources and Breeding. St. Petersburg, Publiching house " Intan".

Lagunes-Espinoza, L.C., C. Huyghe and J. Papineau 2000. Genetic variation for pod wall proportion in Lupinus albus L. Plant Breed. $119: 421-425$.

Liu, J., Z.R. Wang, C. Li, Y.B. Bian and Y. Xiao 2015. Genetic diversity of Pleurotus pulmonarius revealed by RAPD, ISSR, and SRAP fingerprinting. J. Basic. Microbiol. 55 :749-60.

Lopez-Bellido, L., M. Fuentes and J.E. Castillo 2000. Growth and yield of white lupin under Mediterranean conditions: Effect of plant density. Agronomy Journal 92 :200-205.

Mut, H., A. Gulumser, I. Ayan, Z. Acar, U. Basaran and O. Onal-Asci 2012. Effects of cultivar, inoculation, and sowing date in seed yield and yield components of lupin. Journal of Plant Nutrition, 35 (9) :1290-1302.

Mulayim, M., A. Tamkoc and M. Babaoglu 2002. Sweet white lupins versus local bitter genotype: agronomic characteristics as affected by different planting densities in the Goller region of Turkey. European Journal of Agronomy 17 :181189

Noffsinger, S.L., C. Huyghe and E. van Santen 2000. Analysis of grain-yield components and inflorescence levels in wintertype white lupin. Agron. J. $92: 1195-1202$.

Omer, M. A. M., E. A. Mohamed, I. A. M. Ahmed, A. A. Yagoub and E. E. Babiker 2016. Effect of different processing methods on anti-nutrients content and protein quality of improved lupin (Lupinus albus L.) cultivar seeds. Turkish Journal of Agriculture - Food Science and Technology, 4 (1): 9-16.

Raman, R., D.J. Luckett and H. Raman 2008. Estimation of genetic diversity in albus lupin (Lupinus albus L.) using DART and genic markers. In :Lupins for Health and Wealth Proceedings of the $12^{\text {th }}$ International Lupin Conference. eds. J.A. Palta and J.B. Berger, Fremantle, Western Australia. International Lupin Association, Canterbury, New Zealand. 14-18 Sept. 
Raza, S. and B. Jornsgard 2002. Screening of white lupin accessions for morphological and yield traits. African Crop Science Journal $13: 135-141$.

Robarts, D. W. H. and A.D. Wolfe 2014. Sequence-related amplified polymorphism (SRAP) markers: A potential resource for studies in plant molecular biology. Appl Plant Sci. 2 : http://dx.doi.org/10.3732/apps.1400017.

Rocio, M., E. Esteban, P. Zornoza and M.J. Sierra 2013. Could an abandoned mercury mine area be cropped? Environmental Research $125: 150-159$.

Rohlf, F. 2005. Ntsys-pc, Numerical taxonomy and multivariate analysis system, version 2.2. Exeter Publishing Ltd., New York.

Rubio, J., J.I. Cubero, L.M. Martyn, M.J. Suso and F. Flores 2004. Biplot analysis of trait relations of white lupin in Spain. Euphytica 135: 217-224.

Sabaghnia, N. 2015. Investigation of some morphological traits in studied lentil (Lens culinaris Medik.) genotypes grown with foliar application of nanosized ferric oxide. Annales UMCS, Biologia. $69: 29-38$.

Sipsas, S. 2008. Lupin products - Concepts and reality. In Lupins for Health and Wealth. In :Proceedings of the $12^{\text {th }}$
International Lupin Conference : 506-513 eds. J.A. Palta and J.B. Berger, Freemantle, Australia 14-18 September.

Steel, R.G.D. and J.H. Torrie 1980. Principles and Procedures of Statistics: A Biometrical Approach. 2 ed. New York: McGraw-Hill Publ. Company.

Tabrett S, D. Blyth, N. Bourne and B. Glencross 2012. Digestibility of Lupinus albus lupin mean in barramundi (Lates calcarifer). Aquaculture $364: 1-5$.

Wang, T., J. Xu, X.X. Zhang and L.J. Zhao 2012. Genetic relationship of 43 cultivars of Viola tricolor and Viola cornuta using SRAP marker. Scientia Agricultura Sinica 45 :496-502.

Wilkins, R. J. and R. Jones 2000. Alternative home-grown protein sources for ruminants in the United Kingdom. Animal Feed Science and Technology 85 :23-32.

Yorgancilar, M., M. Babaoglu, E.E. Hakki and E. Atalay 2009. Determination of the relationship among Old World Lupin (Lupinus sp.) species using RAPD and ISSR markers. African Journal of Biotechnology $8: 3524-3530$.

Zhukovsky, P.M. 1929. A contribution to the knowledge of genus Lupinus Tourn. Bull. Apll. Bot. Gen. Pl.-Breed. 3:16294. 